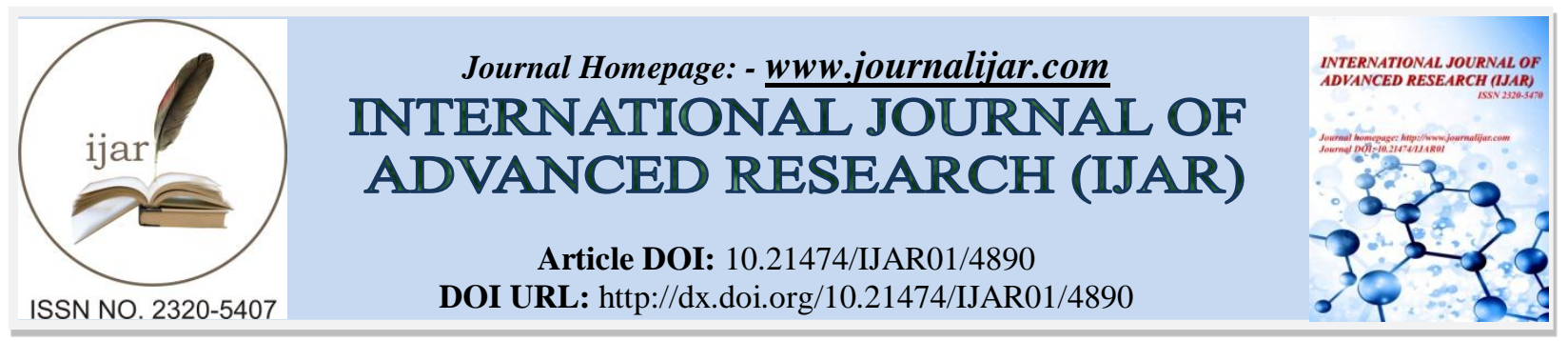

RESEARCH ARTICLE

\title{
PHYSICO-CHEMICAL QUALITY OF SURFACE WATER WITHIN LONG BANGA UPPER HEART OF BORNEO ISLAND CATCHMENTS.
}

\section{Geoffery James Gerusu ${ }^{1}$ and Nur Bazilah Ismail ${ }^{2}$.}

1. Senior Lecturer, Department of Forestry Science, Faculty of Agriculture and Food Sciences; UPM Bintulu Sarawak Campus, Jalan Nyabau, 97000 Bintulu, Sarawak, Malaysia.

2. Researcher, Research, Development, and Innovation Division; Forest Department Sarawak, Wisma Sumber Alam, Jalan Stadium, Petra Jaya, 93660 Kuching, Sarawak, Malaysia.

\section{Manuscript Info}

\section{Manuscript History}

Received: 19 May 2017

Final Accepted: 21 June 2017

Published: July 2017

Key words:-

Water quality, physio-chemical parameters, Long Banga catchment,

Heart of Borneo, Sarawak

\section{Abstract}

\begin{abstract}
Assessment of physico-chemical water quality of Long Banga upper catchment in Heart of Borneo area, Sarawak, Malaysia was conducted during Scientific Expedition 2016. The purpose was to ascertain the water quality level within these highland catchments. The results were compared with Malaysia Interim National Water Quality Standards (INWQS) standard for water quality. Results showed positive levels to aquatic life in general, with high dissolved oxygen concentrations with an average of $7.1 \mathrm{mg} / \mathrm{l}$ and also less conductivity, TDS and TSS in all sampling points. Water samples results from $\mathrm{Sg}$. Ano revealed slight variation of high concentration of COD which fall under Class III of water quality standards compared to other streams. High concentration of COD might be attributed to production of organic acids during breakdown of organic matter. Generally, the results obtained indicated that physio-chemical properties of all 27 sampling points within Long Banga catchment was characterized as unpolluted and conserved in its natural state.
\end{abstract}

Copy Right, IJAR, 2017,. All rights reserved.

\section{Introduction:-}

Safe and clean water is vital for ecosystems and civilizations worldwide. In other words, water is an essential resource that sustains life on earth, changes in the natural quality and distribution of water have ecological impacts that can be sometimes be devastating. About $97 \%$ of our raw water supply for agricultural, domestic and industrial needs are derived from surface water sources primarily rivers (Lim, 2008). Considering the prevalence of forests as drinking water source areas, management activities that can potentially affect water quality are often a concern to the public.

The Sarawak sector of the Heart of Borneo initiatives is sited along its border with Indonesian Kalimantan, Brunei Darussalam and Sabah stretching from Batang Ai in the south-west to Merapok in the north-east (Lawas District). It cover an area $\mathbf{2 . 1}$ million ha or some 16.4\% Sarawak land's area including the interior parts of six Divisions, namely Sri Aman, Sarikei, Sibu, Kapit, Miri and Limbang (Sarawak Forest Department, 2016). Long Banga, Ulu Baram, Sarawak, Malaysia is one of the areas that covered under Heart of Borneo initiatives and it is located at $437 \mathrm{~m}$ above sea level and near to Kalimantan, Indonesia border. The area is mountainous and several peaks nearby reach $1000 \mathrm{~m}$. According to the local people of Long Banga, their main water resource comes from Sg. Ano 
catchment the upper catchment of Baram tributary. Thus, forest in the catchment area should not be disturbed by any means and need to be preserved as they are the repository of natural heritage besides their association with rivers which are important water resources (Uzzell, 1989).

In Malaysia, the use of the Interim National Water Quality Standards (INWQS) is enforced by the Department of Environment (Ainon and Yanti, 2008). The main purpose of INWQS is to classify rivers into classes within the water quality parameters. The classes ranged from Class I to V (I, IIA, IIB, III, IV, and V). It is an important standardisation measurement that is most helpful in assessing and monitoring surface water.

As the surrounding local communities living around the study area and consume stream water directly as drinking and other domestic purposes, thus it is vital to determine the physicochemical characteristics of these surface water quality within Heart of Borneo catchment. Considering this study provides a good knowledge of the qualities of surface water and its suitability for daily household usage. Therefore; this study was formulated to determine the quality of the surface water by assessing the levels of some physicochemical parameters, which justifies the quality of a safe and clean water for the usage of local communities.

\section{Materials and Methods:-}

\section{Study Sites:-}

There are 9 streams involved in this study; namely Sg. Puak, Sg. Ma’o Kecil, Sg. Ma'o Besar, Sg. Sekuan, Sg. Baleh, Sg. Pesi, Sg. Kebok, Sg. Sena, and Sg. Ano. Those study sites are shown in Figure 1.

\section{Water Quality Parameters:-}

This study involves 9 water quality parameters. A multi instrument parameter Eutech Cyberscan Handheld PCD650 is used at every sampling points to measure $\mathrm{pH}$, temperature, conductivity, and total dissolved solids meanwhile dissolved oxygen was determined by using portable and handheld multi-parameter water quality meter model WQC24 (DKK-TOA) for in-situ reading. Turbidity was measured using portable turbidimeter Thermo Scientific Eutech TN-100.

A few water samples were collected and brought back to the laboratory for further analysis which involves parameters like ammoniacal nitrogen, chemical oxygen demand, and total suspended solids. Ammoniacal nitrogen was tested by using HACH method meanwhile chemical oxygen demand and total suspended solids were analysed following the Standard Methods (APHA). All the analyses were done in triplicates.

The results of water quality in the study were then classified based on Interim National Water Quality Standards (INWQS) procedures.

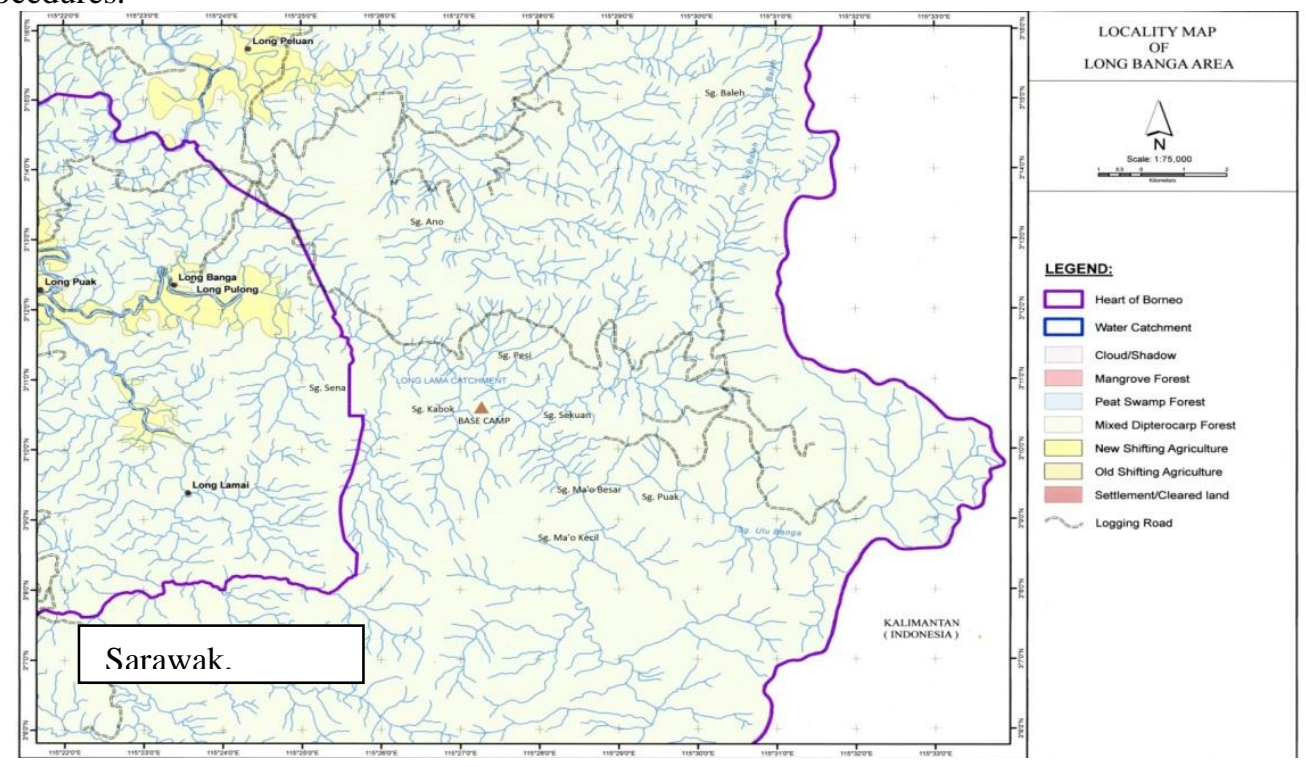

Figure 1:- Map of Long Banga, Sarawak, Malaysia. 


\section{Results and Discussion:-}

Table 1 listed the 9 streams chosen as sampling stations as well as the simple characteristics of each station. Generally the flow of the streams in the study sites was quite swift, semi clear water, the bottom rocks and the banks lined with boulders and rocks. The shore vegetation consists of riverine forest with mixed hilly dipterocarp trees.

Table 2 presents water quality data obtained during expedition and laboratory analysis.

Table 1:- Characteristics of sampling points observed within Long Banga catchment

\begin{tabular}{|l|l|}
\hline \multicolumn{1}{|c|}{ Streams } & \multicolumn{1}{c|}{ Description } \\
\hline Sg. Puak & Swift flowing, semi clear water, rocky bottom \\
\hline Sg. Ma'o Kecil & Swift flowing, clear water, rocky bottom \\
\hline Sg. Ma'o Besar & Swift flowing, clear water, rocky bottom \\
\hline Sg. Sekuan & Swift flowing and semi clear water, rocky bottom, some parts with small waterfalls \\
\hline Sg. Pesi & Slow flowing, clear water, rocky bottom \\
\hline Sg. Kabok & Swift flowing, semi clear water, rocky bottom \\
\hline Sg. Sena & Slow flowing, semi clear water, rocky bottom \\
\hline Sg. Ano & $\begin{array}{l}\text { Slow flowing, partially covered by forest canopy at the downstream. } \\
\text { Swift flowing, rocky bottom, has waterfall at the upper stream (Arol Ano Waterfall) }\end{array}$ \\
\hline Sg. Baleh & Swift flowing, semi clear water, rocky bottom \\
\hline
\end{tabular}

Table 2:- Average water quality parameters in the streams of Long Banga.

\begin{tabular}{|l|c|c|c|c|c|c|c|c|c|}
\hline \multicolumn{1}{|c|}{ STREAMS } & $\begin{array}{c}\text { Temp } \\
\left({ }^{\circ} \mathbf{C}\right)\end{array}$ & $\mathbf{p H}$ & $\begin{array}{c}\text { Turbidity } \\
(\mathbf{N T U})\end{array}$ & $\begin{array}{c}\text { DO } \\
(\mathbf{m g} / \mathbf{L})\end{array}$ & $\begin{array}{c}\text { Conductivity } \\
(\boldsymbol{\mu s})\end{array}$ & $\begin{array}{c}\text { TDS } \\
(\mathbf{m g} / \mathbf{L})\end{array}$ & $\begin{array}{c}\text { TSS } \\
(\mathbf{m g} / \mathbf{L})\end{array}$ & $\begin{array}{c}\text { COD } \\
(\mathbf{m g} / \mathbf{L})\end{array}$ & $\begin{array}{c}\text { NH3N } \\
(\mathbf{m g} / \mathbf{L})\end{array}$ \\
\hline Sg. Puak & 24.5 & 8.1 & 11.96 & 7.0 & 73.64 & 69.50 & 40.67 & 34.56 & 0.06 \\
\hline Sg. Ma'o Kecil & 22.6 & 8.1 & 2.43 & 8.7 & 147.3 & 14.00 & 3.33 & 47.60 & 0.04 \\
\hline Sg. Ma'o Besar & 23.3 & 8.15 & 3.07 & 8.5 & 75.0 & 70.79 & 2.67 & 43.25 & 0.06 \\
\hline Sg. Sekuan & 22.4 & 7.72 & 20.9 & 9.1 & 68.23 & 64.42 & 14.67 & 34.56 & 0.12 \\
\hline Sg. Baleh & 22.9 & 7.53 & 26.73 & 4.0 & 50.66 & 47.81 & 22.67 & 46.08 & 0.05 \\
\hline Sg. Pesi & 22.0 & 7.53 & 24.63 & 7.1 & 85.62 & 80.80 & 37.33 & 40.09 & 0.05 \\
\hline Sg. Kabok & 22.1 & 7.70 & 5.43 & 6.9 & 72.47 & 68.55 & 8.0 & 34.56 & 0.08 \\
\hline Sg. Sena & 23.8 & 7.34 & 8.2 & 6.8 & 61.48 & 58.00 & 7.33 & 46.08 & 0.13 \\
\hline Sg. Ano & 21.9 & 7.22 & 10.34 & 5.8 & 18.2 & 17.18 & 22.22 & 51.84 & 0.15 \\
\hline
\end{tabular}

Interim National Water Quality Standards (INWQS) is a preliminary means of assessing a river which it provides a number that pollutant should not exceed. The INWQS defined six classes (I, IIA, IIB, III, IV, and V) based in the descending order of water quality vis-à-vis Class I being the "best" and Class V being the "worst". INWQS for each river are shown in Table 3 below:

Table 3:- INWQS for streams of Long Banga

\begin{tabular}{|c|c|c|c|c|c|c|c|c|c|}
\hline \multirow[b]{2}{*}{ STREAMS } & \multicolumn{9}{|c|}{ PARAMETERS/WATER CLASSES } \\
\hline & $\begin{array}{l}\text { Temp } \\
\left({ }^{\circ} \mathrm{C}\right)\end{array}$ & pH & $\begin{array}{c}\text { Turbidity } \\
\text { (NTU) }\end{array}$ & $\begin{array}{c}\text { DO } \\
(\mathrm{mg} / \mathrm{L})\end{array}$ & $\begin{array}{c}\text { Conductivity } \\
(\mu s)\end{array}$ & $\begin{array}{c}\text { TDS } \\
(\mathrm{mg} / \mathrm{L})\end{array}$ & $\begin{array}{c}\text { TSS } \\
(\mathrm{mg} / \mathrm{L})\end{array}$ & $\begin{array}{c}\text { COD } \\
(\mathrm{mg} / \mathrm{L})\end{array}$ & $\begin{array}{r}\mathrm{NH}_{3} \mathrm{~N} \\
(\mathbf{m g} / \mathbf{L})\end{array}$ \\
\hline Sg. Puak & $\mathrm{N}$ & $\mathrm{I}$ & IIA & I & I & $\mathrm{I}$ & IIA & IIB-III & $\mathrm{I}$ \\
\hline $\begin{array}{l}\text { Sg. Ma’o } \\
\text { Kecil }\end{array}$ & $\mathrm{N}$ & I & I & I & I & I & I & IIB-III & I \\
\hline $\begin{array}{l}\text { Sg. Ma'o } \\
\text { Besar }\end{array}$ & $\mathrm{N}$ & I & I & I & I & I & I & IIB-III & I \\
\hline Sg. Sekuan & $\mathrm{N}$ & I & IIA & I & I & I & $\mathrm{I}$ & IIB-III & I \\
\hline Sg. Baleh & $\mathrm{N}$ & $\mathrm{I}$ & IIA & III & $\mathrm{I}$ & $\mathrm{I}$ & $\mathrm{I}$ & IIB-III & $\mathrm{I}$ \\
\hline Sg. Pesi & $\mathrm{N}$ & $\mathrm{I}$ & IIA & I & I & I & IIA & IIB-III & I \\
\hline Sg. Kabok & $\mathrm{N}$ & I & I & IIA & I & I & I & IIB-III & I \\
\hline Sg. Sena & $\mathrm{N}$ & I & IIA & IIA & I & I & I & IIB-III & IIA \\
\hline Sg. Ano & $\mathrm{N}$ & I & IIA & IIB & I & I & I & III & IIA \\
\hline
\end{tabular}


In-situ and physico-chemical parameters:-

To get a better comparison between all streams, data was interpreted in graph as shown in Figure 2 to 9 .

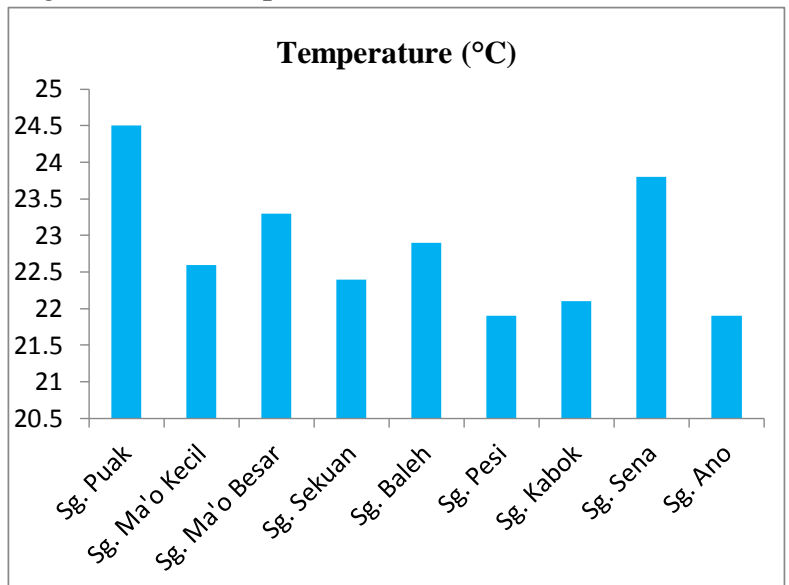

Figure 2:- Average temperature

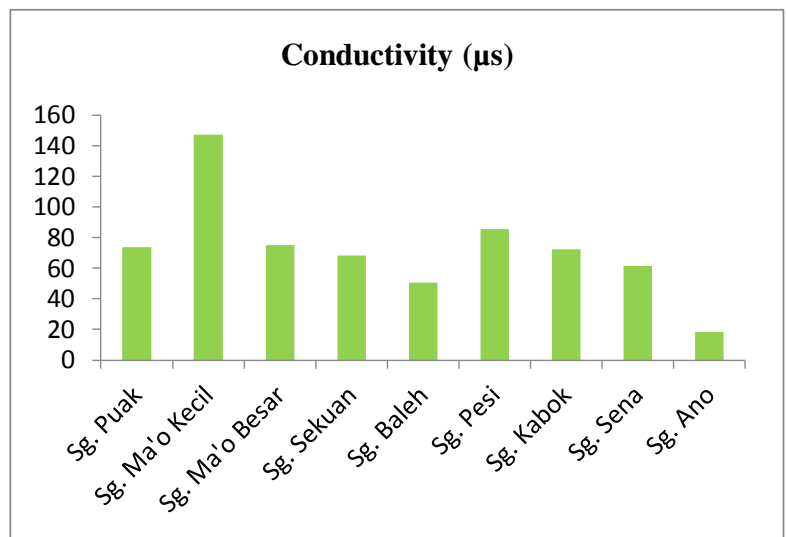

Figure 4:- Average conductivity

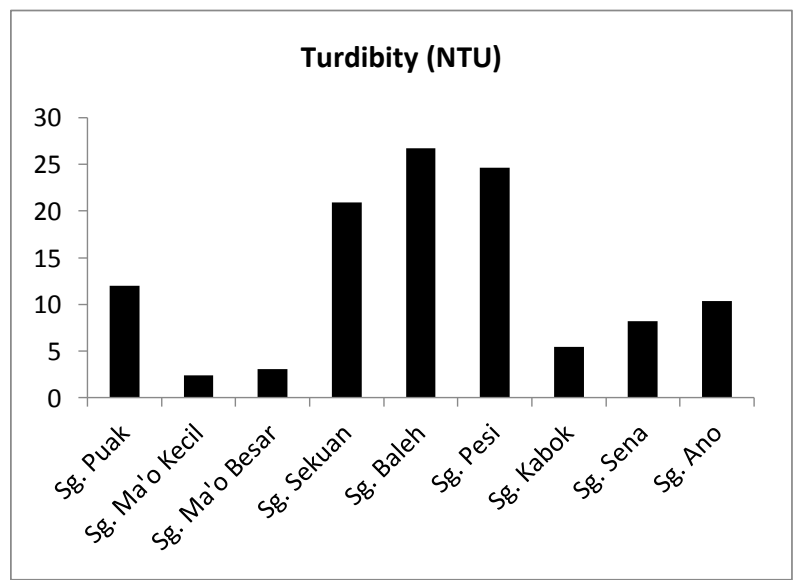

Figure 6:- Average turbidity

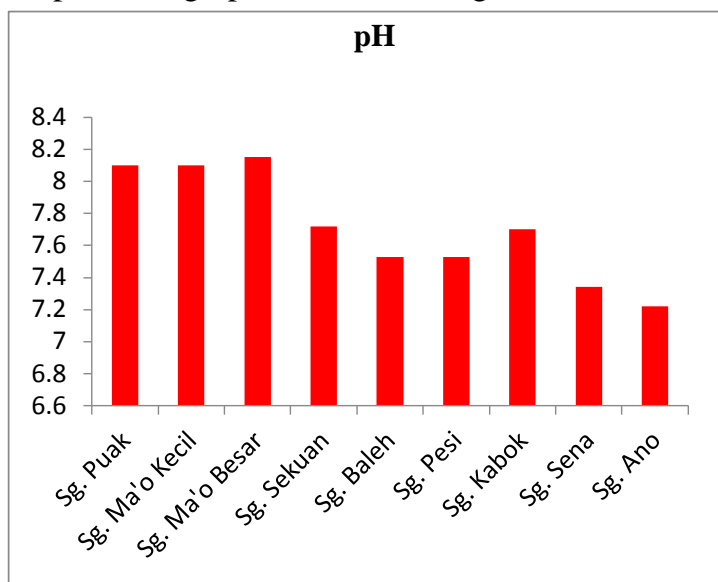

Figure 3:- Average pH.

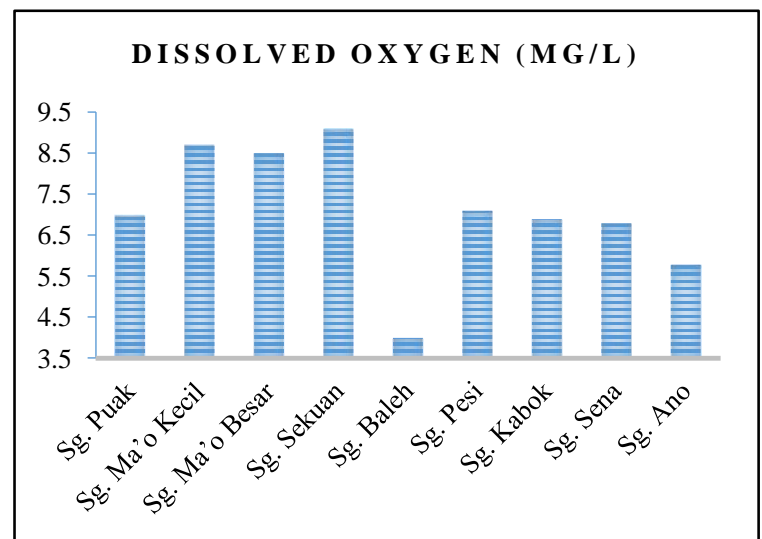

Figure 5:- Average dissolved oxygen

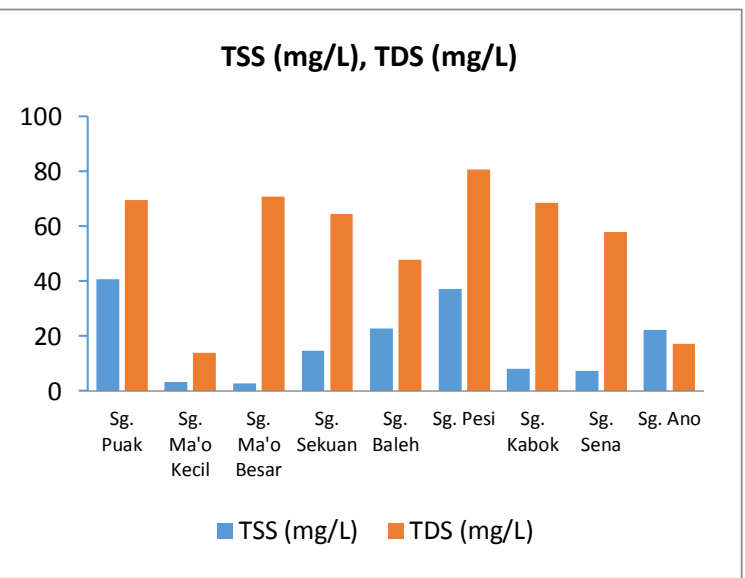

Figure 7:- Average total suspended and dissolved solids. 


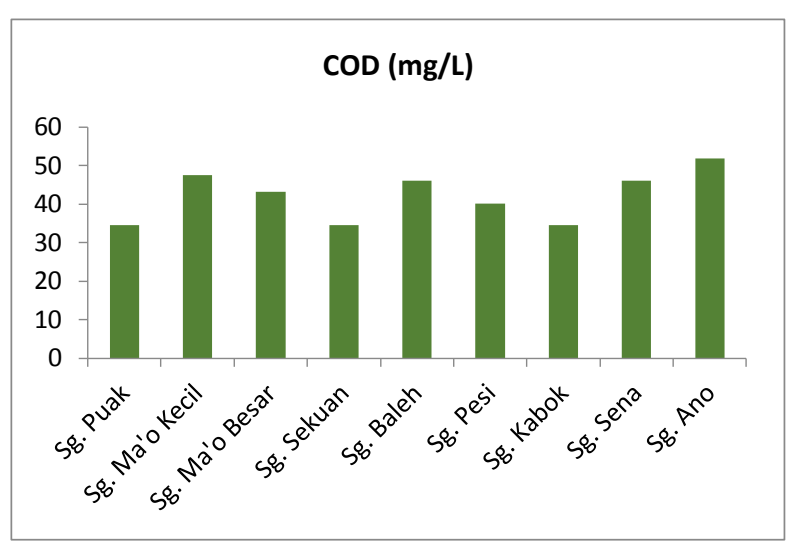

Figure 8:- Average chemical oxygen demand

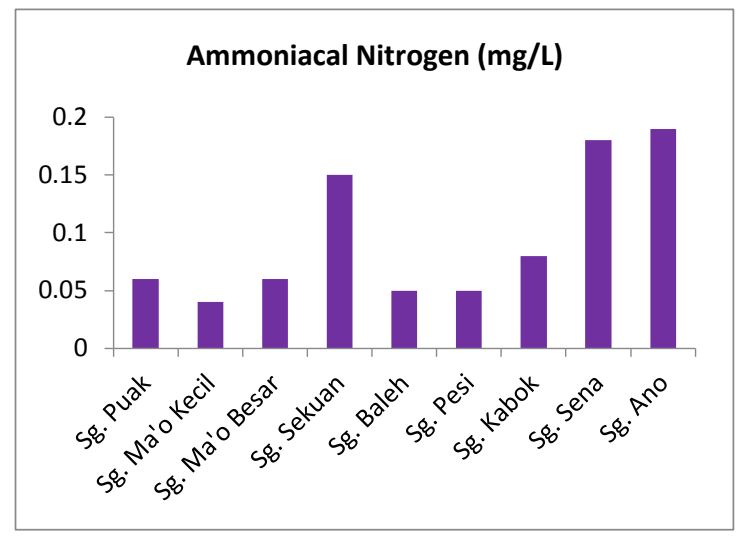

Figure 9:- Average ammoniacal nitrogen

This study revealed that the average temperature for all streams were between $21.9^{\circ} \mathrm{C}$ and $24.5^{\circ} \mathrm{C}$. $\mathrm{Sg}$. Ano showed the lowest water temperature meanwhile $\mathrm{Sg}$. Puak is the highest with reading $24.5^{\circ} \mathrm{C}$. This condition is considered normal for waterbody despite the differences in temperature range. Sg. Ano located in forested areas and this forest canopy provides cover for waterbody hence the low temperature while the exposed waterbody had resulted in the higher water temperature.

$\mathrm{pH}$ is one of the common water quality tests performed and it is a measurement used to measure water acidity ${ }^{1}$. The $\mathrm{pH}$ of a water body is very important in determining its water quality since it affects other chemical reaction (Fakayode, 2005). The concentration range of hydronium ions suitable for the existence of most biological life is narrow, typically between $\mathrm{pH} 6$ to 9 . In this study, the $\mathrm{pH}$ value for streams ranged at 7.22 to 8.15. Based on the INWQS, all the streams showed an average $\mathrm{pH}$ level within class I and considered not polluted.

The dissolved oxygen within nine (9) monitored small catchments within Heart of Borneo areas were generally considered as high concentrations with an average of $7.1 \mathrm{mg} / \mathrm{l}$ of dissolved oxygen. Five (5) catchments were classified in Class I which represent excellent condition of oxygen rate. These results indicated that these five small catchments considered as healthy forested catchment areas with high DO concentrations availability within the streams system. Furthermore, the present of two species of damselfly from Family Calopterygidae were found along Sg. Puak as a vital bioindicator of a clean water of these catchments. One of the damselfly species was identified as Matronoides cyaneipennis which considered only can be found and tolerate with clean water system. Two catchments were classified in Class IIA and Sg. Ano was categorized under class IIB. The DO results gained from Sg. Ano however contradicted with temperature reading as it's gave lowest temperature whereby, the colder the water, the more oxygen it can hold. Thus, low dissolved oxygen found within this catchments suggested to be affected by slow flowing or temporarily stagnant water condition of certain areas along the Sg. Ano stream system. Sg. Baleh catchment revealed the lowest DO concentration and was classified in Class III which consider as moderate water quality. This finding was suggested caused by more openness canopy cover that might be due to previous logging activities within this catchment area.

Other parameter tested was turbidity. Turbidity is caused by particles suspended or dissolved in water that scatter light making the water appear murky or cloudy. From the result above; Sg. Baleh revealed the highest turbidity reading among all streams. This finding was supported by lowest dissolved oxygen reading measured from this catchment. As turbidity is affected by the presence of dissolved and suspended solids, the total dissolved solids result coincides with turbidity. Overall, all streams showed turbidity index within Class I and Class IIA. The total suspended and dissolved solids results also fall under Class I and Class IIA. Natural processes in forested areas such as landslides and channel erosion can affect water quality by creating temporarily increased concentrations of sediments ${ }^{7}$. The main source of solids in natural waters is water, rainfall, and soil erosion by wind ${ }^{1}$. Although people often think that clean water is clear, even unpolluted water can have dissolved or suspended particles that may lessen its clarity but do not diminish its quality.

In this study, the chemical oxygen demand (COD) results ranged from $34.56 \mathrm{mg} / \mathrm{L}$ to $51.84 \mathrm{mg} / \mathrm{L}$. COD is a measurement of the oxygen required to oxidize soluble and particulate organic matter in water (Miroslav et al., 
2007) and it is often used as an alternate to BOD due to shorter length of testing time. Sg. Ano recorded the highest COD concentration $(51.84 \mathrm{mg} / \mathrm{L})$ which probably means high amount of oxidizable organic material compare to the other streams. This result revealed that slow movement or temporarily stagnant water condition of stream water may cause high oxidization activities within the stream system.

The only nutrient parameter tested in this study was ammoniacal-nitrogen $\left(\mathrm{NH}_{3} \mathrm{~N}\right)$. A form of inorganic nitrogen, ammoniacal nitrogen is a measure for the amount of ammonia which is a toxic pollutant. The average amount of ammoniacal nitrogen in all streams were recorded between $0.04 \mathrm{mg} / \mathrm{L}$ to $0.15 \mathrm{mg} / \mathrm{L}$. Sg. Ano showed the highest concentration $(0.15 \mathrm{mg} / \mathrm{L})$ and this could be due to decomposition of organic matter. However as it falls under Class IIA according to INWQS, the river still considered as not polluted. Most of the streams showed no significant pollution with concentrations less than $0.1 \mathrm{mg} / \mathrm{L}$ which is an expected value for natural and undisturbed water bodies.

\section{Conclusion:-}

It is important to realise that even without any human interference, there is no "distilled water" flowing through a river. There will always be non-zero "background" concentrations of many substances, resulting from natural processes. For instance, mountainous streams which are continuously eroding the rocks over which they flow, and as such carry some of the eroded materials with them. Natural water quality varies from place to place, with the seasons, the climate, and with the types of soils and rocks through which water moves.

Based on findings and analyses with supported by the INWQS classification, the water quality of upper streams in Long Banga catchments, Heart of Borneo is still at positive level. The undisturbed forest of Long Banga is vitally important for maintaining the good condition of river water. Forest area must be protected, as it provides the function of watershed area that supplies a clean and undisturbed water to be used by human. It is recommended that continuous monthly or yearly monitoring is conducted to collect water quality information. This long-term monitoring is needed to track water quality changes over time.

\section{References:-}

1. Ainon, H. and Yanti, H. (2008). Water quality and bacterial study in Tasik Chini, Pahang. Proceedings of Taal 2008, the $12^{\text {th }}$ World Lake Conference.

2. Fakayode, S. O. (2005). Impact assessment of industrial effluent on water quality of the receiving Alaro River in Ibadan, Nigeria. Ajaem-Ragae. 10:1-13.

3. Forest Department Sarawak official website. http://www.forestry.sarawak.gov.my. Retrieved on 3 October 2016.

4. Harr, R. D. and Fredriksen, R. L. (1988). Water quality after logging small watersheds within the Bull Run watershed, Oregon. Water Resour. Bull. 24(5):1103-1111.

5. Lim, C. H. (2008). Dialogue on "Water Environment Partnership in Asia (WEPA)". Ministry of Natural Resources and Environment.

6. Miroslav, R., Mohd, H. A., Ahmad, Z. A. (2007). Analisis Air. Scholar Press (M) Sdn. Bhd. Malaysia. 105 pp.

7. Nor Azmizah, A., Reuben, N., Abdullah, O. (2014). Report on the assessment of water quality in Deramakot Forest Reserve 2014.

8. Uzzell, D. L. (1989). Heritage interpretation: The natural and built, Vol. 1. London Belhaven Press. 